\title{
POSITION OF MANDIBULAR CONDYLES DURING STABILIZATION SPLINT WEARING
}

\author{
Anja Profozić ${ }^{1}$, Antonia Plazibat ${ }^{1}$, Antonia Polašek $^{1}$, Manuela Pliško $^{1}$ and Samir Čimić \\ ${ }^{1} 6^{\text {th }}$ year student, School of Dental Medicine, University of Zagreb, Zagreb, Croatia; \\ ${ }^{2}$ Department of Removable Prosthodontics, School of Dental Medicine, University of Zagreb, Zagreb, Croatia
}

\begin{abstract}
SUMMARY - The purpose of this study was to determine the position of mandibular condyles during wearing of stabilization splints with different thickness. Two stabilization splints were made for 10 completely dentate participants. First splint was made with minimal $1 \mathrm{~mm}$ distance at molar area between the upper and lower teeth, while the second splint was made $3 \mathrm{~mm}$ higher than the first splint. Condylar position measurements during splint wearing were done using ultrasound jaw tracking device with six degrees of freedom at the antero-posterior $(\mathrm{x})$, vertical $(\mathrm{y})$ and lateral $(\mathrm{z})$ axes. Linear deviation values were calculated from the values of the Cartesian coordinate system. The mean value of linear deviation between the habitual occlusion and the occlusion with stabilization splint made at $1 \mathrm{~mm}$ distance in molar area was $2.04 \pm 1.18 \mathrm{~mm}$, while with stabilization splint made $3 \mathrm{~mm}$ higher than the first one it was $2.32 \pm 1.24 \mathrm{~mm}$. Independent samples $\mathrm{T}$ test did not confirm statistically significant difference in deviation values between the splints of different thickness. Raising stabilization splint height does not change significantly the position of the condyle within the temporomandibular joint. Higher condylar distraction in the temporomandibular joint cannot be expected with 'thicker' stabilization splint.
\end{abstract}

Key words: Prosthodontics; Splints; Temporomandibular joint disorders; Mandibular condyle; Dental occlusion

\section{Introduction}

Temporomandibular disorders (TMDs) is a collective term that involves several clinical problems affecting the masticatory muscles, temporomandibular joints and associated structures ${ }^{1}$. TMDs are defined as conditions producing abnormal, incomplete or impaired function of the temporomandibular joint ${ }^{2}$. Studies showed different prevalence of TMD signs and symptoms in various populations ${ }^{3,4}$. In general population, the prevalence of TMD is between $40 \%$ and $60 \%$ (at least one recognizable sign of TMD). One of the most widely used treatments of TMD are occlusal splints ${ }^{6}$. An occlusal splint is a removable de-

Correspondence to: Assist. Prof. Samir Čimic, DDM, PhD, Department of Removable Prosthodontics, School of Dental Medicine, University of Zagreb, Gundulićeva 5, HR-10000 Zagreb, Croatia

E-mail: scimic@sfzg.hr

Received December 14, 2016, accepted November 11, 2017 vice usually made of hard acrylic that fits over the occlusal and incisal surface of the teeth in one arch, creating precise occlusal contact with the teeth of the opposing $\operatorname{arch}^{5}$. There are several types of occlusal splints and stabilization splint is the most widespread form. Stabilization splint is generally used in the treatment of various types of TMDs and for prevention of the nocturnal bruxism effects on the teeth ${ }^{7}$.

Although stabilization splint has a widespread use in therapy of TMDs, the mechanism of its action remains unclear and controversial ${ }^{8}$. Okeson ${ }^{5}$ mentions at least eight features that are common to all types of occlusal splints and that may explain why occlusal splints reduce the symptoms associated with TMDs, such as alteration of the occlusal condition, alteration of the condylar position, increase in the vertical dimension, cognitive awareness, a change in peripheral input to the central nervous system, natural musculoskeletal recovery, placebo effect, and regression to the mean. 
Mandibular position during occlusal splint wearing was studied with different approaches: cast analysis in the articulator ${ }^{9}$, magnetic resonance imaging ${ }^{10,11}$, transcranial radiography ${ }^{12}$, computed tomography ${ }^{13}$, and with jaw tracking devices ${ }^{14}$. Obrez and Gallo ${ }^{15}$ state that only since the development of three-dimensional tracking systems supplemented with sophisticated mathematical transformation of the data obtained, it has been possible to estimate condylar movements relatively accurately.

The purpose of this in vivo study was to investigate the position of mandibular condyles during wearing of occlusal splint with the use of the ultrasound jaw tracking device with six degrees of freedom, and to determine the influence of splint thickness on the condylar position.

\section{Materials and Methods}

The study included 10 participants, mean age $23.8 \pm 0.92$ years. All participants were completely dentate (except for third molars), with Angle class I occlusal relationship, no signs and symptoms of TMD, and without previous extensive occlusal/restorative therapy. Each participant had to give a written informed consent, which was approved by the Ethics Committee of the School of Dental Medicine, University of Zagreb.

Measurements of condylar movements were done using an ultrasound jaw tracking device with six degrees of freedom (Arcus Digma II, Kavo, Biberach, Germany). Lower bow of the device is attached to the mandibular dental arch with paraocclusal tray and has ultrasound transmitters. Upper bow (facebow) has receivers of ultrasound pulses. The device measures the real-time latency period between transmitted and received ultrasound pulses. With the six degrees of freedom concept, the software of the device calculates position of the lower jaw.

First, two irreversible hydrocolloid impressions of the upper jaw and two irreversible hydrocolloid impressions of the lower jaw (Aroma Fine Plus, GC, Tokyo, Japan) were made for each participant. Casts were poured from the type IV gypsum (Polistone, Polident, Volcja Draga, Slovenia). On the upper cast, acrylic base with a front jig out of light polymerized acrylic (Unitray, Polident, Volcja Draga, Slovenia) was made. Care was taken that the acrylic base with a front jig sits identical on both upper casts. If a fit of the acrylic base with a front jig was different between casts, acrylic base with a front jig was repeated. On one of the lower casts, a paraocclusal tray was made from light-polymerized acrylic resin following the manufacturer's recommendations. On the next appointment, centric relation was recorded with the chin point guidance method, using the acrylic base with a front jig and thermoplastic registration material (Bite Compound, GC, Tokyo, Japan). Both upper casts were transferred to the articulator (ProtarEvo 7, Kavo, Biberach, Germany) with identical facebow registration. Lower casts were set in the articulator using (identical) centric relation record. On the upper casts, stabilization splints were made. First stabilization splint (splint1) was made at the required height of $1 \mathrm{~mm}$ in molar area between the upper and lower teeth. Height of an incisal pin of the articulator was recorded. Second splint (splint2) was made at the recorded height of the incisal pin plus $3 \mathrm{~mm}$.

Occlusal splints were made in the articulator (anterior and posterior occlusal determinants were set to average values: sagittal condylar inclination $30^{\circ}$, Bennett angle $15^{\circ}$, immediate side shift $0 \mathrm{~mm}$, incisal guide angle $35^{\circ}$ ) from cold curing acrylic resin (Orthosin Uni, Schütz Dental, Rosbach, Germany), with final heat-pressure polymerization (Ivomat IP3, Ivoclar Vivadent, Schaan, Liechtenstein). Acrylic resin was modeled on a vacuum pressed thermoforming foil (Erkodur $0.5 \mathrm{~mm}$ thickness, Erkodent, Pfalzgraffenweiler, Germany). After polymerization, occlusal splints were returned to the articulator for grinding and precise definition of occlusal contacts. All contacts in the articulator were checked and defined with 8- $\mu \mathrm{m}$ occlusal foil (Interdent, Celje, Slovenia). It was insisted on minimally one contact per tooth on the occlusal splint, from the upper canine to the last molar. Front teeth were not in contact (except for distal part of the canine). Canine guidance was achieved in left and right laterotrusion. Before recording of the condylar position, splints were placed in the mouth and occlusal contacts were checked. Occlusal contacts were checked with $8-\mu \mathrm{m}$ occlusal foil, insisting on the left-right simultaneous and equivalent contacts, with minimally one contact per tooth from distal part of the upper canine to the last molar. If necessary, occlusal adjustment of the stabilization splint was carried out with grinding to achieve desired occlusion; mandibular cusps had even contact with the occlusal splint. 


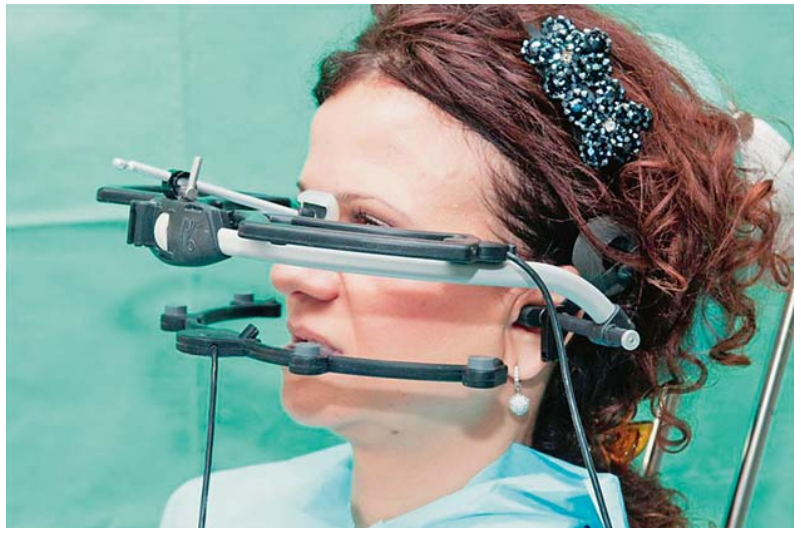

Fig. 1. Jaw tracking device with six degrees of freedom.

Next, condylar position with stabilization splints was recorded using the ultrasound jaw tracking device. Participants were seated in upright posture. A paraocclusal tray was fixed in the lower jaw using acrylic resin for temporary restorations (Structur, Voco, Cuxhaven, Germany). The paraocclusal tray and the fixation material were not in contact with the upper teeth. Upper bow (facebow) and lower bow of the device were mounted (Fig. 1). Measurements were carried out in the Electronic Position Analysis module of the device. The Electronic Position Analysis module measures distances of the measured position of the left and right condyles in relation to the reference position of the condyles. First was recorded habitual occlusion as a reference position for comparison with first and second stabilization splint. After recording the reference position, first and second splint were positioned on the upper teeth, and the condylar position at stabilization splint occlusion was recorded.

Within the corresponding computer program (Kavo Integrated Desktop, Kavo, Biberach, Germany) deviations were calculated between the position of habitual occlusion and the occlusion with splint1, and between the position of habitual occlusion and the occlusion with splint2. All deviations were calculated at the level of the left and right mandibular condyles: deviation at $\mathrm{x}$ (anterior-posterior) axis, deviation at $\mathrm{y}$ (superior-inferior) axis and deviation at $\mathrm{z}$ (lateral) axis. Linear deviation values between the condylar position at the habitual occlusion and condylar position at occlusion with splint $1 /$ splint 2 were also calculated from the deviations measured in the Cartesian coordinate system. Condylar deviations on the right and left sides

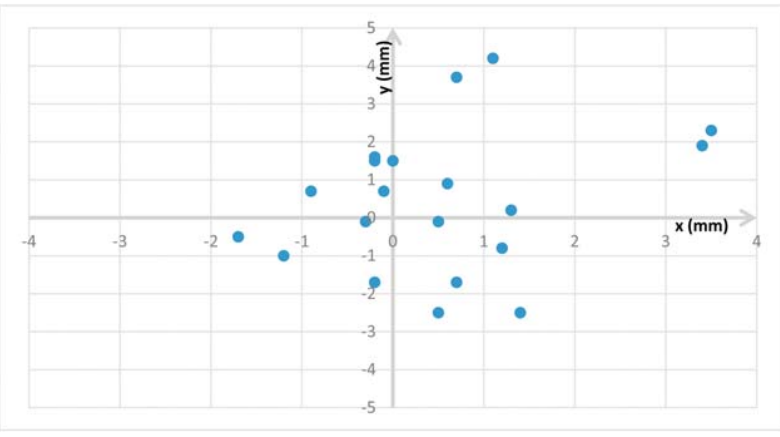

Fig. 2. Condylar deviation values between the position of habitual occlusion and occlusion with splint wearing for splint1 group for all participants.

*At x (anterior-posterior) axis negative values define posterior direction; at y (superior- inferior) axis negative values define inferior direction.

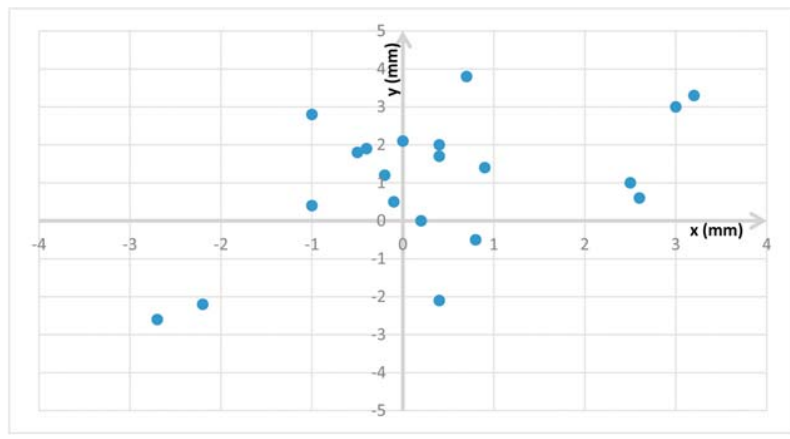

Fig. 3. Condylar deviation values between the position of habitual occlusion and occlusion with splint wearing for splint2 group for all participants.

*At x (anterior-posterior) axis negative values define posterior direction; at y (superior-inferior) axis negative values define inferior direction.

were treated as one sample, as in similar studies ${ }^{16}$. Descriptive statistics was calculated (SPSS statistics 17.0). Deviation values between splint1 and splint 2 were compared with independent samples $\mathrm{T}$ test, and values below 0.05 were considered statistically significant.

\section{Results}

Figures 2 and 3 show individual deviation values for all participants for the splint 1 and splint 2 groups. Tables 1 and 2 show mean deviation values for splint 1 and splint 2 groups at $x, y$ and $z$ axes. The mean value of linear deviation between the condylar position at habitual occlusion and condylar position at occlusion of 
Table 1. Deviation values between condylar position at habitual occlusion and condylar position during occlusion of stabilization splint for splint1 group

\begin{tabular}{|l|l|l|l|l|l|}
\hline Axis & $\mathrm{N}$ & Min & Max & Mean & SD \\
\hline $\mathrm{x}$ & 20 & -1.70 & 3.50 & 0.51 & 1.30 \\
$\mathrm{y}$ & 20 & -2.50 & 4.20 & 0.42 & 1.86 \\
$\mathrm{z}$ & 20 & -0.70 & 0.30 & -0.18 & 0.35 \\
\hline
\end{tabular}

$\mathrm{x}=$ anterior-posterior axis; $\mathrm{y}=$ superior-inferior axis; $\mathrm{z}=$ lateral axis; negative values at $\mathrm{x}$ axis mean posterior direction, at $\mathrm{y}$ axis inferior direction, and at $\mathrm{z}$ axis left side.

Table 2. Deviation values between condylar position at babitual occlusion and condylar position during occlusion of stabilization splint for splint 2 group

\begin{tabular}{|l|l|l|l|l|l|}
\hline & $\mathrm{N}$ & Min & Max & Mean & SD \\
\hline $\mathrm{x}$ & 20 & -2.70 & 3.20 & 0.35 & 1.57 \\
$\mathrm{y}$ & 20 & -2.60 & 3.80 & 1.01 & 1.80 \\
$\mathrm{z}$ & 20 & -0.50 & 1.40 & -0.01 & 0.52 \\
\hline
\end{tabular}

$\mathrm{x}=$ anterior-posterior axis; $\mathrm{y}=$ superior-inferior axis; $\mathrm{z}=$ lateral axis; negative values at $\mathrm{x}$ axis mean posterior direction, at $\mathrm{y}$ axis inferior direction, and at $\mathrm{z}$ axis left side.

the stabilization splint was $2.04 \pm 1.18 \mathrm{~mm}$ (minimum $0.59 \mathrm{~mm}$, maximum $4.35 \mathrm{~mm}$ ) for the splint1 group. The mean linear deviation value between the condylar position at habitual occlusion and condylar position at occlusion of the stabilization splint was $2.32 \pm 1.24 \mathrm{~mm}$ (minimum $0.22 \mathrm{~mm}$, maximum $4.60 \mathrm{~mm}$ ) for the splint 2 group. Independent samples $\mathrm{T}$ test did not show statistically significant differences in deviation values of the $x(\alpha=0.76), y(\alpha=0.32)$ and $z(\alpha=0.25)$ axes, or in linear deviation values $(\alpha=0.47)$ between the splint 1 and splint 2 groups. In relation to the habitual occlusion, in splint1 group 6 condyles showed anterior-superior, 5 anterior-inferior, 4 posterior-superior, 4 posterior-inferior and 1 condyle showed superior position at occlusion with the stabilization splint. In relation to the habitual occlusion, in splint 2 group 8 condyles showed anterior-superior, 2 anterior-inferior, 6 posterior-superior, 2 posterior-inferior, 1 superior, and 1 condyle showed anterior position at occlusion with the stabilization splint. At 5 condyles, direction of condylar movement in relation to the habitual occlusion was different between the splint 1 and splint 2 groups.

\section{Discussion}

The purpose of this study was to investigate differences in condylar position during occlusion with stabilization splints of different thickness. Similar values of condylar deviation from the habitual occlusion were observed for the splint 1 and splint 2 groups. No statistically significant difference was found between condylar deviation values of the splint 1 and splint 2 groups.

Condylar position within the temporomandibular joint is considered as an important factor of the occlusal splints during treatment of $\mathrm{TMD}^{12}$. Studies showed a relationship between the condylar position and etiopathogenesis of TMD ${ }^{17,18}$. Demling et al. ${ }^{16}$ investigated condylar position at stabilization and pivot appliances. Insertion of stabilization appliance caused a mean $0.2 \pm 0.5 \mathrm{~mm}$ sagittal and $0.8 \pm 0.5 \mathrm{~mm}$ vertical condylar movement, with average anterior and inferior direction. Chu et al. ${ }^{11}$ using magnetic resonance imaging scans investigated the effect of interocclusal appliances on the mandibular position. Most of the participants had anterior and inferior condylar position with acrylic splint (3-mm interincisal distance) compared to habitual occlusion. Ekberg et al. ${ }^{19}$ and Hasegawa et al. ${ }^{10}$ obtained similar results. Although the results of the present investigation (Figs. 2 and 3) are contrary to previous studies of the condylar position with occlusal splints ${ }^{10,11,16,19}$, the present study results can be interpreted as similar to the studies of condylar position at the centric relation occlusion ${ }^{20-24}$. Investigations of the centric relation occlusion ${ }^{20-24}$ confirmed superior condylar position with anterior or posterior component in most participants compared to the habitual occlusion. Considering that stabilization splints are made at the position of centric relation, superior condylar position with stabilization splint in relation to the habitual occlusion can be expected, as confirmed by present study results (Figs. 2 and 3).

The main function of the interocclusal appliance therapy is considered to be reduction in temporomandibular joint loading and reduction in muscle activity ${ }^{11}$. Casares et al..$^{25}$ studied intra-articular pressure of the temporomandibular joint during function of the lower jaw using a pressure transducer. Using stabilization splints, the authors confirmed $31.24 \%$ reduction of the intra-articular pressure compared with maximum intercuspidation ${ }^{25}$. Abekura et al. ${ }^{26}$ investigated relation 
of the occlusal splint vertical thickness and nocturnal EMG activities of masticatory muscles. The analysis of muscle activities led to a conclusion that occlusal splint with 3-mm vertical thickness at the central incisors was superior to the occlusal splint with $6-\mathrm{mm}$ vertical thickness. According to the results of the present study (no statistically significant differences in condylar position with different splint thickness), it is concluded that there is optimal height for occlusal splints. Since the thicker splint wearing is more uncomfortable for patients, stabilization splint made at approximately 3 $\mathrm{mm}$ at central incisors or $1 \mathrm{~mm}$ at molar area can be recommended. Chu et al. ${ }^{11}$ studied mandibular condylar position in patients with interocclusal appliances. Using 3D magnetic resonance imaging of the temporomandibular joint, the authors determined constancy of the condylar position with 3-mm thick splint, while $5-\mathrm{mm}$ thick splint showed variable results for all participants. Although Chu et al. ${ }^{11}$ used different methodology for condylar position imaging (magnetic resonance imaging), the results can be interpreted as similar to the present study results ( $25 \%$ of condyles showed different direction of movement with splint1 and splint2). Raising the splint height does not lead to predictable condylar position within the joint. It is arguable whether greater splint height leads to change in spatial position of the condyle, disc and fossa.

Different studies used different control points for measuring splint thickness. Ettlin et al. ${ }^{27}$ measured distance between the mesial marginal ridge of the first molar and the opposing occlusal surfaces. Hasegawa et $a l .{ }^{10}$ measured gap at the cervix of the maxillary central incisor. The present study used molar space and incisal pin of the articulator. Occlusal splints resulting from different measuring control points can be interpreted as with similar thickness, still, for better comparison of the results between the studies, standardized control points would be optimal.

\section{Conclusion}

With acrylic stabilization splint made at the centric relation position, superior condylar position in relation to habitual occlusion is expected. Raising the stabilization splint thickness does not necessarily lead to change in condylar position or the position does not alter significantly.

\section{References}

1. Alajbeg IZ, Gikić M, Valentić-Peruzović M. Changes in pain intensity and oral health-related quality of life in patients with temporomandibular disorders during stabilization splint therapy - a pilot study. Acta Clin Croat. 2014;53:7-16.

2. The glossary of prosthodontic terms. J Prosthet Dent. 2005; 94:10-92. doi: 10.1016/j.prosdent.2005.03.013

3. Carlsson GE. Epidemiology and treatment need for temporomandibular disorders. J Orofac Pain. 1999;13:232-7.

4. Magnusson T, Egermark I, Carlsson GE. A longitudinal epidemiologic study of signs and symptoms of temporomandibular disorders from 15 to 35 years of age. J Orofac Pain. 2000;14: $310-9$.

5. Okeson J. Management of temporomandibular disorders and occlusion. $7^{\text {th }}$ ed. Maryland Heights: Mosby, 2012.

6. Badel T, Čimić S, Munitić M, Zadravec D, Bašić Kes V, Kraljević Šimunković S. Clinical view of the temporomandibular joint disorder. Acta Clin Croat. 2014;53:462-70.

7. Badel T, Pandurić J, Kraljević S, Dulčić N. Initial treatment of prosthetic patients with a Michigan splint. Acta Stomatol Croat. 2003;37:207-10.

8. Reichardt G, Miyakawa Y, Otsuka T, Sato S. The mandibular response to occlusal relief using a flat guidance splint. Int J Stomatol Occlusion Med. 2013;6:134-9. doi: 10.1007/s12548-013-0093-8

9. Fantini SM, Paiva JB, Rino Neto J, Dominguez GC, Abrao J, Vigoritto JW. Increase of condylar displacement between centric relation and maximal habitual intercuspation after occlusal splint therapy. Braz Oral Res. 2005;19:176-82. doi: 10.1590/S1806-83242005000300004

10. Hasegawa Y, Kakimoto N, Tomita S, Honda K, Tanaka Y, Yagi K, Kondo J, Nagashima T, Ono T, Maeda Y. Movement of the mandibular condyle and articular disc on placement of an occlusal splint. Oral Surg Oral Med Oral Pathol Oral Radiol Endod. 2011;112:640-7. doi: 10.1016/j.tripleo.2011.06.013

11. Chu SA, Suvinen TI, Clement JG, Reade PC. The effect of interocclusal appliances on temporomandibular joints as assessed by $3 \mathrm{D}$ reconstruction of MRI scans. Aust Dent J. 2001;46:18-23. doi: 10.1111/j.1834-7819.2001.tb00269.x

12. Venturelli FA, Zuim PR, Antenucci RM, Garcia AR. Analysis of mandibular position using different methods of location. Acta Odontol Latinoam. 2009;22:155-62.

13. Ok SM, Lee J, Kim YI, Lee JY, Kim KB, Jeong SH. Anterior condylar remodeling observed in stabilization splint therapy for temporomandibular joint osteoarthritis. Oral Surg Oral Med Oral Pathol Oral Radiol. 2014;118:363-70.

doi: 10.1016/j.oooo.2014.05.022

14. Seedorf H, Seetzen F, Scholz A, Sadat-Khonsari MR, Kirsch I, Jude HD. Impact of posterior occlusal support on the condylar position. J Oral Rehabil. 2004;31:759-63. doi: 10.1111/j.1365-2842.2004.01421.x

15. Obrez A, Gallo LM. Anatomy and function of the TMJ. In: Laskin DM, Greene CS, Hylander WL, editors. TMDs: An 
Evidence-Based Approach to Diagnosis and Treatment. Hanover Park: Quintessence Publishing Co., 2006; p 39-41.

16. Demling A, Fauska K, Ismail F, Stiesch M. A comparison of change in condylar position in asymptomatic volunteers utilizing a stabilization and a pivot appliance. Cranio. 2009;27: 54-61. doi: 10.1179/crn.2009.009

17. Padala S, Padmanabhan S, Chithranjan AB. Comparative evaluation of condylar position in symptomatic (TMJ dysfunction) and asymptomatic individuals. Indian J Dent Res. 2012;23:122. doi: 10.4103/0970-9290.99060

18. Čimić S, Žaja M, Kraljević Šimunkovic S, Kopić M, Ćatić A. Influence of occlusal interference on the mandibular condylar position. Acta Stomatol Croat. 2016;50:116-21. doi: $10.1564 /$ asc $50 / 2 / 3$

19. Ekberg EC, Sabet ME, Petersson A, Nilner M. Occlusal appliance therapy in a short-term perspective in patients with temporomandibular disorders correlated to condyle position. Int $\mathrm{J}$ Prosthodont. 1998;11:263-8.

20. Wood DP, Elliott RW. Reproducibility of the centric relation bite registration technique. Angle Orthod. 1994;64:211-20.

21. Klar NA, Kulbersh R, Freeland T, Kaczynski R. Maximum intercuspation-centric relation disharmony in 200 consecutively finished cases in a gnathologlcally oriented practice. Semin Orthod. 2003;9:109-16. doi: 10.1053/sodo.2003.34034
22. Weffort SY, de Fantini SM. Condylar displacement between centric relation and maximum intercuspation in symptomatic and asymptomatic individuals. Angle Orthod. 2010;80:835-42. doi: 10.2319/090909-510.1

23. Cimic S, Badel T, Kraljevic Simunkovic S, Pavicin IS, Catic A. Centric slide in different Angless classes of occlusion. Ann Anat. 2016;203:47-51. doi: 10.1016/j.aanat.2015.09.001

24. Utt TW, Meyers CE Jr., Wierzba TF, Hondrum SO. A threedimensional comparison of condylar position changes between centric relation and centric occlusion using the mandibular position indicator. Am J Orthod Dentofacial Orthop. 1995; 107:298-308. doi: 10.1016/S0889-5406(95)70146-X

25. Casares G, Thomas A, Carmona J, Acero J, Vila CN. Influence of oral stabilization appliances in intra-articular pressure of the temporomandibular joint. Cranio. 2014;32:219-23. doi: 10.1179/0886963413Z.00000000030

26. Abekura H, Yokomura M, Sadamori S, Hamada T. The initial effects of occlusal splint vertical thickness on the nocturnal EMG activities of masticatory muscles in subjects with a bruxism habit. Int J Prosthodont. 2008;21:116-20.

27. Ettlin DA, Mang H, Colombo V, Palla S, Gallo LM. Stereometric assessment of TMJ space variation by occlusal splints. J Dent Res. 2008;87:877-81. doi: $10.1177 / 154405910808700903$

Sažetak

\section{ISTRAŽIVANJE POLOŽAJA MANDIBULARNOG KONDILA KOD NOŠENJA STABILIZACIJSKE UDLAGE}

\section{A. Profozič, A. Plazibat, A. Polašek, M. Pliško i S. Čimić}

Svrha ovoga istraživanja bila je odrediti položaj mandibularnih kondila tijekom nošenja stabilizacijskih udlaga različite debljine. Kod 10 potpuno ozubljenih ispitanika su izrađene po dvije stabilizacijske udlage. Prva stabilizacijska udlaga je napravljena na visini od $1 \mathrm{~mm}$ u području molara, dok je druga udlaga napravljena $3 \mathrm{~mm}$ više u odnosu na prvu udlagu. Položaji lijevog i desnog kondila tijekom nošenja udlage su izmjereni pomoću uređaja za snimanje kretnji donje čeljusti na temelju šest stupnjeva slobode (u odnosu na referentni položaj habitualne okluzije): na razini x (antero-posteriorne), y (vertikalne) i z (lateralne) osi. Iz vrijednosti Kartezijevog koordinatnog sustava su izračunate linearne vrijednosti odstupanja. Linearno odstupanje između položaja habitualne okluzije i okluzije sa stabilizacijskom udlagom visine $1 \mathrm{~mm}$ u području molara bilo je prosječno $2,04 \pm 1,18 \mathrm{~mm}$, dok je kod udlage visine prve udlage $+3 \mathrm{~mm}$ iznosilo $2,32 \pm 1,24 \mathrm{~mm}$. T testom nezavisnih uzoraka nije utvrđena statistički značajna razlika u vrijednostima odstupanja između dviju udlaga različite debljine. Povećanjem visine stabilizacijske udlage ne mijenja se značajno položaj kondila unutar temporomandibularnog zgloba. S debljom udlagom se ne može očekivati veća kondilarna distrakcija unutar zgloba.

Ključne riječi: Stomatološka protetika; Udlage; Temporomandibularni zglob, poremećaji; Mandibularni kondil; Zubna okluzija 